\title{
PReS-FINAL-2063: Proposed criteria for activity, damage and impact of juvenile idiopathic arthritis associated uveitis: consensus effort from the multinational interdisciplinary working group for uveitis in childhood (MIWGUC)
}

\author{
I Foeldvari ${ }^{*}$, A Heiligenhaus $^{2}$, J Anton $^{3}$, R Ramanan ${ }^{4}$, C Edelsten $^{5}$, T Saurenmann ${ }^{6}$, B Bodaghi $^{7}$, K Kotaniemi $^{8}$, \\ S Nielsen ${ }^{9}$, E Rabinovich ${ }^{10}$, Multinational Interdisciplinary Working Group for Uveitis in Childhood (MIWGUC) \\ From 20th Pediatric Rheumatology European Society (PReS) Congress \\ Ljubljana, Slovenia. 25-29 September 2013
}

\section{Introduction}

Uveitis is the most common extraartricular manifesation of juvenile idiopathic arthritis (JIA) with an.incidence of approx. 10 - 15 per 100,000 children. Uveitis, a potentially blinding disorder, is present in approx $10-18 \%$ of JIA patients, with a wide spectrum of presentations. Despite advances in treatment of childhood arthritis there are no definitions for assessment of activity, damage and impact of JIA associated uveitis.

\section{Objectives}

The purpose of our efforts was to develop and gain consensus on such definitions as activity and damage.

\section{Methods}

At the second consensus meeting of the MIWGUC group, using a Delphi method we developed definitions for activity, damage and impact of disease based on already published outcome measures [1].

\section{Results}

The following items were included and listed in Table 1. The items were derived from the previously proposed and already published list of outcome measures [1].

${ }^{1}$ Hamburger Zentrum für Kinder-und Jugendrheumatologie, Hamburg, Germany

Full list of author information is available at the end of the article
Following items were selected to present activity: anterior chamber cells, flare, vusual acuity, syncechiae,macular edema ocular hyptony, ocular hypertension, CHAQ, number of medication and local eyedrops. Folowing items were selected to present damaga:flare, visual acuity, synechiae,cataract, macular edema, ocular hypotony and hypertony, glaucoma, disc edema, band keratopahty, epiretinal membranes and overall uveiits disability VAS.

\section{Conclusion}

We will validate these proposed definitions propsectively in a JIA associated uveitis cohort. Based on the results, we will weight these measures to develop an overall scoring system.

\section{Disclosure of interest}

None declared.

\begin{abstract}
Authors' details
${ }^{1}$ Hamburger Zentrum für Kinder-und Jugendrheumatologie, Hamburg, Germany. ${ }^{2}$ Ophthalmology, Müster, Germany. ${ }^{3}$ Pediatric Rheumatology, Barcelona, Spain. ${ }^{4}$ Pediatric Rheumatology, Bristol, UK. ${ }^{5}$ Great Ormond Street Hospital, London, UK. ${ }^{6}$ PediatricRheumatology, Zürich, Switzerland. ${ }^{7}$ Ophthalmology, Paris, France. ${ }^{8}$ Ophthalmologist, Helsinki, Finland. ${ }^{9}$ Pediatric Rheumatology, Copenhagen, Denmark. ${ }^{10}$ Pediatric Rheumatology, Durham,
\end{abstract} USA.

Published: 5 December 2013 


\section{Reference}

1. Heiligenhaus A, et al: Proposed outcome measures for prospective clinical trials in juvenile idiopathic arthritis-associated uveitis: a consensus effort from the multinational interdisciplinary working group for uveitis in childhood. Arthritis Care Res (Hoboken) 2012, 64(9):1365-72.

\section{doi:10.1186/1546-0096-11-S2-P75}

Cite this article as: Foeldvari et al:: PReS-FINAL-2063: Proposed criteria for activity, damage and impact of juvenile idiopathic arthritis associated uveitis: consensus effort from the multinational interdisciplinary working group for uveitis in childhood (MIWGUC). Pediatric Rheumatology 2013 11(Suppl 2):P75.

Submit your next manuscript to BioMed Central and take full advantage of:

- Convenient online submission

- Thorough peer review

- No space constraints or color figure charges

- Immediate publication on acceptance

- Inclusion in PubMed, CAS, Scopus and Google Scholar

- Research which is freely available for redistribution

Submit your manuscript at www.biomedcentral.com/submit
Ciomed Central 